\title{
Induced systemic resistance in beet plants infected with Meloidogyne javanica
}

\author{
Paula J.G. Débia ${ }^{1}$, Beatriz C. Bolanho Barros ${ }^{2}$, Heriksen H. Puerari ${ }^{3}$, Júlio C.A. Ferreira ${ }^{4}$, \\ and Claudia R. Dias-Arieira ${ }^{1^{*}}$
}

\begin{abstract}
${ }^{1}$ Universidade Estadual de Maringá, Departamento de Agronomia, Programa de Pós-Graduação em Agronomia, Avenida Colombo, 5790, CEP 87020-900, Maringá, Paraná, Brasil. "Corresponding author (crdarieira@uem.br).

${ }^{2}$ Universidade Estadual de Maringá, Departamento de Tecnologia, Avenida Ângelo Moreira da Fonseca, 1800, CEP 87506-370, Umuarama, Paraná, Brasil.

${ }^{3}$ Universidade Federal de Goiás, Escola de Agronomia, Rodovia Goiânia-Nova Veneza, km 0, s/n - Campus Samambaia, CEP 74690900, Goiânia, Goiás, Brasil.

${ }^{4}$ Universidade Estadual Paulista, Faculdade de Ciências Agronômicas, Fazenda Experimental Lageado, CEP 18610-034, Botucatu, São Paulo, Brasil.
\end{abstract}

Received: 24 June 2020; Accepted: 17 September 2020; doi:10.4067/S0718-58392021000100070

\begin{abstract}
Root-knot nematode infection has a direct and negative impact on the commercial value of beet (Beta vulgaris L.) tubers. The aim of this study was to evaluate induced resistance in beet tuberous roots infected with different population levels of Meloidogyne javanica (Treub, 1885) Chitwood, 1949. Plants were inoculated with increasing inoculum levels $(0,1500$, 5000, and 10000 eggs + juveniles [J2]) and treated with different products that can potentially induce resistance: mannanoligosaccharides (MOS), citrus biomass, and acibenzolar- $S$-methyl (ASM). Vegetative, nematological, and enzymatic parameters were evaluated after $60 \mathrm{~d}$. In general, when compared to the control (water), inducers did not promote a positive effect on tuber diameter and weight, regardless of the inoculum level. Only the weight of plants inoculated with 5000 eggs $+\mathrm{J} 2$ and treated with citrus biomass $(40.70 \mathrm{~g})$ increased compared with the control $(32.38 \mathrm{~g})$. The treatments did not reduce the number of galls, nematodes per root system, and nematodes per gram of root. Resistance inducers increased catalase activity (CAT) and phenylalanine ammonia-lyase (PAL) and MOS and ASM were the most effective. The highest CAT activity was for ASM and 5000 eggs $+\mathrm{J} 2$, resulting in $42.44 \%$ compared with the control. The MOS and ASM exhibited the highest PAL activity $\left(0.22\right.$ and $0.15 \mathrm{mg}$ trans-amino acid $\mathrm{h}^{-1} \mathrm{mg}^{-1}$ protein, respectively) compared with the control (0.03 mg trans-amino acid $\mathrm{h}^{-1} \mathrm{mg}^{-1}$ protein) in uninoculated plants. Results led us to conclude that inducers should not be used in isolation to control nematodes in beet. However, deformed tubers can be used in manufacturing, thus preventing food waste. In addition, new rates and application intervals should be evaluated to help control nematodes in beet plants.
\end{abstract}

Key words: Beta vulgaris, induced resistance, root-knot nematodes, vegetative characteristics.

\section{INTRODUCTION}

Beet (Beta vulgaris L.) crops are susceptible to infections caused by Meloidogyne javanica (Treub, 1885) Chitwood, 1949; the main symptom, gall formation in the root system or in the tubers, leads to plant deformation (Hussain et al., 2016). However, beet plants are typically commercialized as tuberous roots in natura; they must therefore have good esthetic features (Tivelli et al., 2011).

The adoption of integrated management procedures that enable effective control of root-knot nematodes is necessary to reduce damage. This can include the application of resistance inducers with elicitors that have less impact on the environment. Induced resistance is a complex mechanism consisting of the activation of latent physical and biochemical 
barriers in the host because these barriers are stimulated by pathogen infections or by host exposure to elicitor molecules (Chaves et al., 2016).

Mannan-oligosaccharides (MOS), citrus biomass, and acibenzolar-S-methyl (ASM) are among the compounds with induction potential that have been investigated to control phytonematodes (Puerari et al., 2013b; Miamoto et al., 2017). The ASM is one of the most studied inducers used to control phytonematodes; moreover, it is one of the strongest synthetic activators of induced systemic resistance because it enables promising outcomes in different pathosystems (Puerari et al., 2013a; 2013b; Hernandes et al., 2017).

Plant defense responses change several primary and secondary metabolism compounds, for example, activation of the metabolic pathway involved in phytoalexin biosynthesis, accumulation of phenolic compounds, and increased activity of key enzymes (Tivelli et al., 2011; Schaffer and Bronnikova, 2012; Chaves et al., 2016) such as peroxidase (POX), catalase (CAT), and phenylalanine ammonia-lyase (PAL), which are characterized by their participation in the plant defense system against oxidative stress. This stress results from pathogen infections and from changes caused by pathogens in plants, including the production of reactive oxygen species (ROS) such as hydrogen peroxide $\left(\mathrm{H}_{2} \mathrm{O}_{2}\right)$; the ROS react to biological molecules and damage cell membranes, proteins, and DNA and can lead to plant death (Melillo et al., 2006; Schaffer and Bronnikova, 2012).

Enzymes such as CAT and POX play a key role in $\mathrm{H}_{2} \mathrm{O}_{2}$ detoxification processes (Chaves et al., 2016). Catalase is directly involved in converting $\mathrm{H}_{2} \mathrm{O}_{2}$ into water and oxygen under stressful conditions when there is ROS accumulation (Glorieux and Calderon, 2017); it also oxidizes substances such as methanol, ethanol, formaldehyde, and formic acid (Chaves et al., 2016). Peroxidase is involved in cell lignification, wound healing, oxidation of phenolic compounds derived from the phenylpropanoid pathway, and in the $\mathrm{H}_{2} \mathrm{O}_{2}$ reduction process (Chaves et al., 2016). The PAL plays an essential role in phenylpropanoid biosynthesis because it catalyzes the first reaction in the phenylpropanoid pathway by converting L-phenylalanine into trans-cinnamic acid and ammonia; it participates in the synthesis of lignin monomers, salicylic acid, and phytoalexins among other phenolic species required in defense processes (MacDonald and D'Cunha, 2007; Medeiros et al., 2015).

Although induced resistance reduces damage caused by nematodes, studies have shown that it does not fully inhibit their action. This occurs because inducers are able to reduce nematode reproduction, but not their penetration and the appearance of symptoms (Chinnasri et al., 2003; Molinari and Baser, 2010). This feature can be a disadvantage when the affected organ is also the commercialized part of the plant. The aforementioned key enzymes not only have functions associated with the plant's defense system but they can have industrial applications once isolated and purified because of their catalytic ability (Cui et al., 2014; Raveendran et al., 2018). Thus, even if the physical features of tubers deteriorate, applying elicitors as an alternative source of enzymes for use in industrial applications increases the amount of CAT, POX, and PAL in the tubers. Given the scarcity of studies about horticultural beets, the aim of the present study was to evaluate vegetative and nematological parameters and the activity of the CAT, POX, and PAL enzymes in tuberous roots at the end of the crop cycle of beet plants treated with different resistance inducers and infected with increasing $M$. javanica populations.

\section{MATERIALS AND METHODS}

The experiment was carried out in a greenhouse from January to March 2017. The experimental design was completely randomized with a $4 \times 4$ factorial arrangement (treatments with potential inducers $\times$ Meloidogyne javanica population levels) for a total of 16 treatments. Each treatment included five replicates for vegetative and nematological parameters and three replicates for enzyme activity analysis.

Beet (Beta vulgaris L.) 'Kestrel' hybrid seeds (Sakata Seed Sudamerica Ltda., Sao Paulo, Brazil) were sown in polypropylene trays filled with Bioplant plant substrate (Bioplant Agrícola Ltda., Nova Ponte, Minas Gerais, Brazil). Fifteen days after sowing, plants were treated with water (control) and the following potential inducers: 1) mannanoligosaccharides (MOS) composed of phosphorylated mannan-oligosaccharides from the cell wall of the Saccharomyces cerevisiae yeast species and bio-complexed with $28.04 \mathrm{~g} \mathrm{~S} \mathrm{~L}^{-1}, 36.90 \mathrm{~g} \mathrm{Cu} \mathrm{L}^{-1}$, and $24.60 \mathrm{~g} \mathrm{Zn} \mathrm{L}^{-1}$ (AGRO-MOS, Alltech Crop Science, Maringá, Paraná, Brazil), 2) citrus biomass derived from $108.3 \mathrm{~g} \mathrm{~L}^{-1}$ organic $\mathrm{C}, 1.71 \mathrm{~g} \mathrm{~B} \mathrm{~L}^{-1}$, polyols, and carboxylic acids (Ecolife, Quinabra-Química Natural Brasileira Ltda., São José dos Campos, São Paulo, Brazil), 
and 3) acibenzolar-S-methyl (ASM) (acibenzolar-S-methyl $500 \mathrm{~g} \mathrm{~kg}^{-1}$; Bion $500 \mathrm{WG}$, Syngenta, São Paulo, Brazil), all of which were applied based on rates (for vegetables) recommended by the manufacturers $\left(1.5,2.0\right.$, and $0.5 \mathrm{~g} \mathrm{~L}^{-1} \mathrm{water}_{\text {, }}$ respectively). Potential inducers were applied on the plants (in the trays) $15 \mathrm{~d}$ after sowing and reapplied $25 \mathrm{~d}$ after the first application; plants shoots were sprayed until reaching the point of surface runoff.

Five days after the first application of induced resistance treatments on the shoots, seedlings were transplanted into pots (1 seedling pot $\left.{ }^{-1}\right)$ filled with $2.8 \mathrm{~L}$ of a mixture consisting of sandy soil, Bioplant substrate, and sand $(2: 1: 1)$. The mixture was previously sterilized at $120^{\circ} \mathrm{C}$ for $2 \mathrm{~h}$. Plants were inoculated with increasing $M$. javanica populations including 0 , 1000, 5000, and 10000 eggs plus eventual second-stage juveniles (J2) per plant. Inocula resulted from a pure nematode population kept in tomato roots and extracted according to the methodology adapted by Boneti and Ferraz (1981); it was calibrated at 1000 eggs $+\mathrm{J} 2$ on a Peters slide under a 400x magnification optical microscope (Motic model B1-252LED, Motic Instruments, Induslab Com. Equip. Laboratórios Ltda., Londrina, Paraná, Brazil). The inocula were placed in the soil in four equidistant holes (approximately $3 \mathrm{~cm}$ deep) around the plant; the holes were closed after inoculum application. Roots were collected and carefully washed in running water $60 \mathrm{~d}$ after inoculation. Subsequently, tuberous root weight was obtained on a semi-analytical scale, whereas tuber diameter was measured with a digital caliper (Pantec Microwatch, São Paulo, Brazil).

Nematological parameters were analyzed as follows: the number of galls per root system was evaluated based on visual analysis and direct counting, eggs were extracted from the roots and tubers according to the method by Charchar et al. (2006) with modifications, and tuberous roots were peeled to remove bark layers approximately $3 \mathrm{~mm}$ thick. Both tuberous and secondary roots were cut into 1 to $2-\mathrm{cm}$ pieces and ground at top speed for $30 \mathrm{~s}$ in a blender containing enough $0.5 \%$ hypochlorite solution to cover the plant material. The suspension was separated in a 60 mesh $(0.250 \mathrm{~mm})$ sieve, which overlapped a 500 mesh $(0.025 \mathrm{~mm})$ sieve, and was washed in plenty of water. The content in the 500 mesh sieve was collected in a beaker. The number of eggs and $\mathbf{J} 2$ were counted on Peters slides under light microscopy. The total number of nematodes was divided by the root weight to obtain the number of nematodes per gram of root.

Extracts of all the material used in the present study were processed for enzymatic analysis. Thus, $0.5 \mathrm{~g}$ plant tissue from each tuberous root was individually macerated in a mortar filled with liquid nitrogen and $4 \mathrm{~mL} 50 \mathrm{mM}$ potassium phosphate buffer (pH 7.0) containing $0.1 \mathrm{mM}$ EDTA (ethylenediaminetetraacetic acid) was added. The extracts were centrifuged (3K30, Sigma Laborzentrifugen $\mathrm{GmbH}$, Osterode am Harz, Germany) at $4{ }^{\circ} \mathrm{C}$ and $4000 \mathrm{~g}$ for $30 \mathrm{~min}$, and the supernatant (enzyme extract) was transferred to $2.0 \mathrm{~mL}$ tubes and stored in a freezer at $-8{ }^{\circ} \mathrm{C}$ for further protein quantification and determination of enzyme activity. Tubes containing enzyme extracts were kept in an ice bath during the enzyme activity evaluations performed in duplicate.

The Bradford test was used to quantify the total protein content in the samples (Bradford, 1976). For this, $50 \mu \mathrm{L}$ enzyme extracts were added to $2.5 \mathrm{~mL}$ Bradford reagent and stirred in a vortex mixer. After $5 \mathrm{~min}$, an absorbance reading was taken with a spectrophotometer (model UV 5200S, Global Trade Technology, Monte Alto, São Paulo, Brazil) at 595 $\mathrm{nm}$. The protein concentration ( $\mathrm{mg} \mathrm{mL}^{-1}$ sample) was determined based on the standard curve of protein concentrations derived from bovine serum albumin.

Catalase (CAT; EC 1.11.1.6) was determined according to the methodology indicated by Góth (1991) and modified by Tománková et al. (2006); some $100 \mu \mathrm{L}$ of enzyme extracts were mixed with $500 \mu \mathrm{L}$ enzyme substrate $(39.740 \mathrm{~mL} 60 \mathrm{mM}$ potassium phosphate buffer at $\mathrm{pH} 7.4$ and $260 \mu \mathrm{L}$ hydrogen peroxide incubated at $37^{\circ} \mathrm{C}$ for $30 \mathrm{~min}$ ). The mixture was kept in a water bath at $37^{\circ} \mathrm{C}$ for $4 \mathrm{~min}$ and $500 \mu \mathrm{L}$ molybdate solution was added to stop the reaction. The CAT activity was calculated based on the difference between the absorbance of the mixture containing the sample and the control (500 $\mu \mathrm{L}$ molybdate solution added before sample incubation in a water bath). The reading was taken with a spectrophotometer at $405 \mathrm{~nm}$ and results were expressed as $\mu \mathrm{mol} \mathrm{min}^{-1} \mathrm{mg}^{-1}$ protein.

Guaiacol peroxidase (POX; EC 1.11.1.7) activity was based on the conversion of guaiacol to tetraguaiacol in the presence of hydrogen peroxide. A mixture consisting of $2.9 \mathrm{~mL}$ substrate and $100 \mu \mathrm{L}$ enzyme extract was used in the process to determine POX activity. Sample absorbance was measured for 1 min with a spectrophotometer (model UV $5200 \mathrm{~S}$ ) at $470 \mathrm{~nm}$. The substrate consisted of $7.25 \mu \mathrm{L}$ guaiacol and $8.874 \mu \mathrm{L} \mathrm{H}_{2} \mathrm{O}_{2}$ diluted in $50 \mathrm{mM}$ potassium phosphate buffer (pH 7.0); it was kept in a water bath at $30^{\circ} \mathrm{C}$ during the analyses. Results were expressed as $\Delta$ abs $470 \mathrm{~nm} \mathrm{~min} \mathrm{mg}^{-1}$ protein (Lusso and Pascholati, 1999). 
Phenylalanine ammonia-lyase (PAL; EC 4.3.1.5) activity was analyzed according to the methodology mentioned by Umesha (2006). The mixture consisted of $100 \mu \mathrm{L}$ enzyme extract in $400 \mu \mathrm{L} 0.025 \mathrm{M}$ Tris-HCl buffer (pH 8.8) and 500 $\mu \mathrm{L} 0.05 \mathrm{M}$ L-phenylalanine solution (825.9 mg diluted in $100 \mathrm{~mL} 0.025 \mathrm{M}$ Tris- $\mathrm{HCl}, \mathrm{pH} 8.8$ ) and it was incubated at $40{ }^{\circ} \mathrm{C}$ for $1 \mathrm{~h}$. After incubation, $60 \mu \mathrm{L} 5 \mathrm{M} \mathrm{HCl}$ was added to the mixture to stop the reaction; this procedure was followed by a reading with a spectrophotometer at $290 \mathrm{~nm}$. The PAL activity was calculated based on the difference between the absorbance of the mixture containing the sample and the control (without added L-phenylalanine). The standard curve was generated based on the trans-cinnamic acid and expressed as $\mathrm{mg}$ trans-amino acid $\mathrm{h}^{-1} \mathrm{mg}^{-1}$ protein.

Results were subjected to ANOVA at the 5\% probability level; significant means recorded for different inducers were compared using Tukey's test at the 5\% probability level. Meanwhile, the nematode population level was evaluated through regression analysis. Analyses were performed with the Sisvar statistical software version 5.6 (Universidade Federal de Lavras, Departamento de Estatística, Lavras, Minas Gerais, Brazil).

\section{RESULTS}

\section{Vegetative parameters}

There was an interaction between induction treatments and $M$. javanica populations for the tuberous root diameter. Based on the analysis applied to this parameter (Figure 1), the water treatment (control) led to a reduced linear tuber diameter as the initial inoculum level increased. Treatments with MOS and ASM showed quadratic adjustments; minimum tuberous root diameters averaged 36.20 and $32.40 \mathrm{~cm}$, respectively, when the inoculum level was approximately 5000 eggs $+\mathrm{J} 2$. Meanwhile, citrus biomass application led to increased tuber diameter; the maximum increase $(42.00 \mathrm{~mm})$ was observed when the inoculum level was approximately 5000 eggs $+\mathrm{J} 2$, whereas the peak of this parameter was recorded at the 4333 eggs $+\mathrm{J} 2$ inoculum level. In general, plants inoculated with up to 5000 eggs $+\mathrm{J} 2 \mathrm{had}$ a smaller tuber diameter than those treated with water, but the treatments did not differ when beet was inoculated with 10000 nematodes.

There was a significant interaction between induction treatments and M. javanica populations for tuber weight (Figure 1). The incidence of nematodes in untreated plants led to a reduced linear tuber weight, which was similar to recordings for tuber diameter. This reduction was also linear in plants treated with MOS and exhibited a quadratic adjustment in plants treated with ASM; the minimum mass was observed when plants were inoculated with 7833 eggs + J2 (Figure 1). The citrus biomass treatment showed no inoculum level adjustment; however, it increased tuber weight from 32.38 to $40.70 \mathrm{~g}$ in the presence of 5000 eggs $+\mathrm{J} 2$ when compared with the control.

Figure 1. Diameter and weight of beet root after $60 \mathrm{~d}$ of treatment with induced resistance and inoculation with different Meloidogyne javanica population levels.
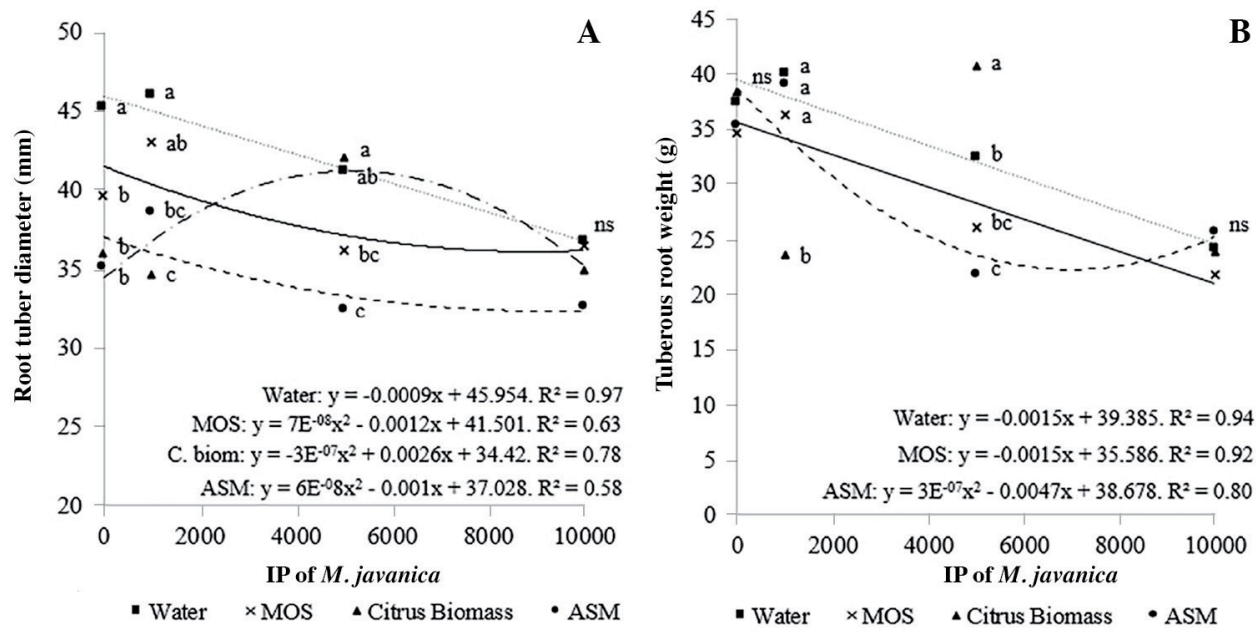

IP: Initial population; MOS: mannan-oligosaccharides; ASM: acibenzolar- $S$-methyl. 


\section{Nematological parameters}

There was an interaction between the number of galls and the studied factors (Figure 2); only the control, MOS, and ASM treatments showed differences in inoculum levels. Untreated inoculated plants and inoculated plants treated with MOS showed a linear increase in the number of galls. However, this parameter exhibited a quadratic adjustment in plants treated with ASM and the maximum mean (266 galls) was observed when the inoculum level reached 6425 eggs + J2. Despite the significant interaction at each inoculum level, the inducers did not differ among levels.

Parameters such as nematodes per root system and nematodes per gram of root also showed an interaction between the studied factors (Figure 2). Plants treated with water, MOS, and citrus biomass showed a linear increase in the number of nematodes per root system as the inoculum level increased (Figure 2). However, there was no regression adjustment for the ASM treatment. Based on the analysis of the effects of different inducers at each inoculum level, there was no reduction in the total number of M. javanica in plants inoculated with 1000 and 5000 eggs $+\mathrm{J} 2$ when compared with the control treatment. The ASM application reduced the number of nematodes per root system in beet plants inoculated with 10000 eggs $+\mathrm{J} 2$.

The number of nematodes per gram of root in inducer-free plants was not affected by the inoculum level (Figure 2); only treatments with inducers recorded significant results for this parameter. The MOS application led to a linear increase in the number of nematodes per gram of root, whereas plants treated with citrus biomass and ASM showed quadratic adjustments in this parameter; the highest values (16 404 and 10872 nematodes per gram of root, respectively) were recorded at the 5000 eggs $+\mathrm{J} 2$ inoculation level. However, based on the evaluation being used, induction treatments did not reduce the number of nematodes per gram of root when compared with the control.

Figure 2. Number of galls and total nematode and nematode per gram of root after $60 \mathrm{~d}$ of treatment with induced resistance and inoculation with different Meloidogyne javanica population levels.
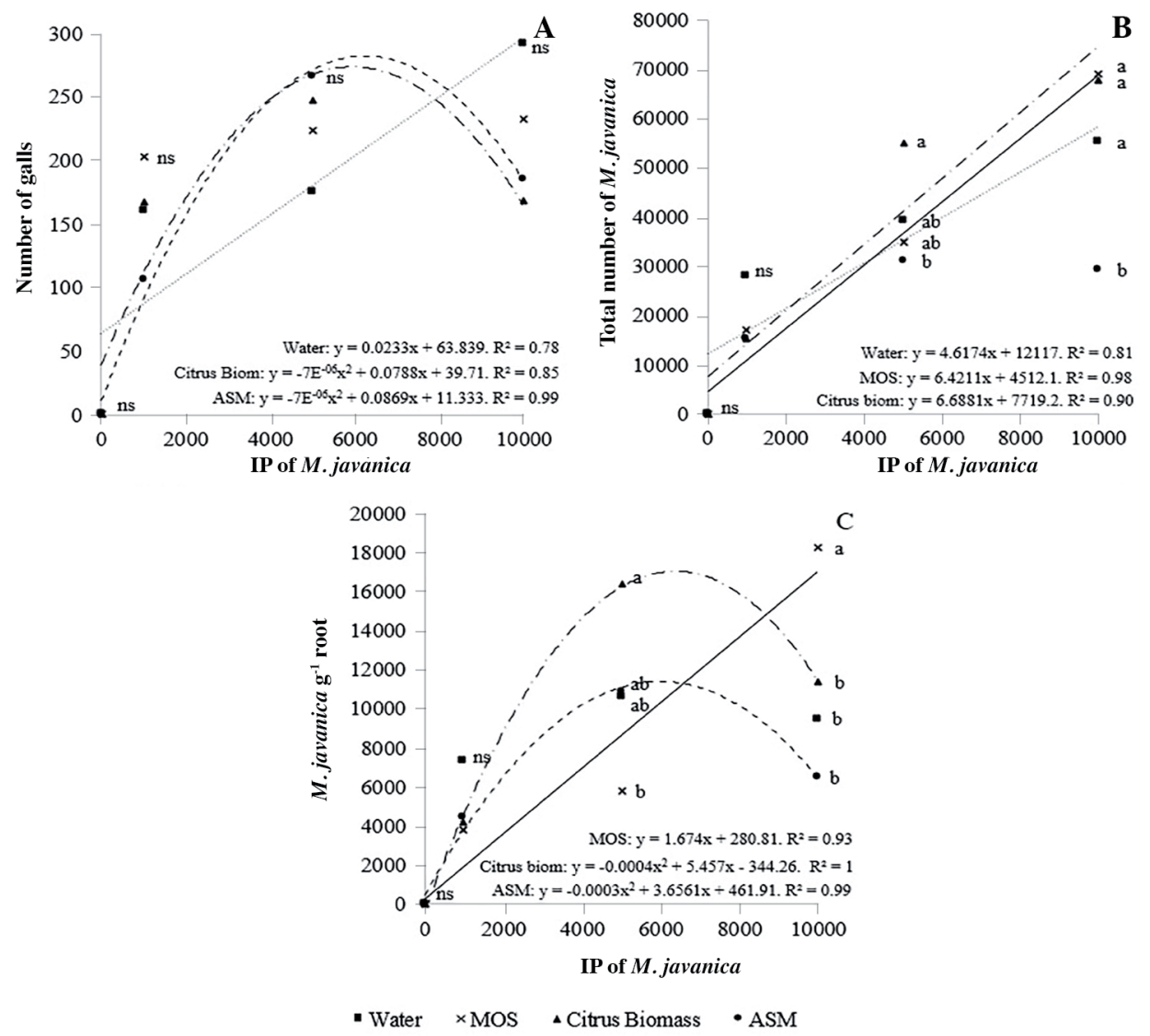

IP: Initial population; MOS: mannan-oligosaccharides; ASM: acibenzolar-S-methyl. 


\section{Enzymatic activity}

Catalase activity showed a significant interaction between induction factors and nematode levels (Figure 3). All treatments showed increased CAT activity with a quadratic adjustment, except for MOS. The highest CAT activity (Figure 3A) was recorded for plants treated with ASM, especially those inoculated with 5000 eggs + J2, which had a 42.44\% CAT activity increase compared with the control plants. Uninoculated plants treated with MOS had the highest CAT activity (29.18

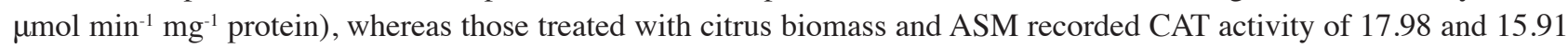
$\mu \mathrm{mol} \mathrm{min}{ }^{-1} \mathrm{mg}^{-1}$ protein, respectively; this outcome was not significantly different from the control $\left(12.42 \mu \mathrm{mol} \mathrm{min}^{-1} \mathrm{mg}^{-1}\right.$ protein). No induction treatment increased CAT activity at the $1000 \mathrm{M}$. javanica eggs $+\mathrm{J} 2$ inoculum level compared with the control. However, if one considers the inducers separately, MOS enabled a higher CAT activity than citrus biomass (24.22 and $17.30 \mu \mathrm{mol} \mathrm{min}{ }^{-1} \mathrm{mg}^{-1}$ protein, respectively). The MOS and ASM inducers applied on plants inoculated with 10000 eggs $+\mathrm{J} 2$ produced a higher enzyme activity than the water and citrus biomass treatments.

The inoculum levels did not affect POX activity (Figure 3B) in plants treated with water, citrus biomass, and MOS. However, plants treated with ASM showed quadratic adjustments for this parameter; the highest mean value (120.56 $\Delta$ abs $470 \mathrm{~nm} \mathrm{~min} \mathrm{mg}^{-1}$ protein) was recorded for plants inoculated with 7400 eggs $+\mathrm{J} 2$. Based on the evaluation of the inducers at each inoculum level, the POX activity in uninoculated plants and in plants inoculated with 1000, 5000, and 10000 eggs $+\mathrm{J} 2$ did not increase. The ASM and MOS inducers enabled higher POX activity than citrus biomass at the 1000 eggs $+\mathrm{J} 2$ inoculum level; however, they did not differ from the untreated control. The ASM recorded higher POX activity than MOS and citrus biomass at the 5000 eggs $+\mathrm{J} 2$ inoculum level; but it did not differ from the control.

Figure 3. Catalase (CAT), peroxidade (POX), and phenylalanine ammonia-lyase (PAL) activity in beet root after $60 \mathrm{~d}$ of treatment with induced resistance and inoculation with different Meloidogyne javanica population levels.
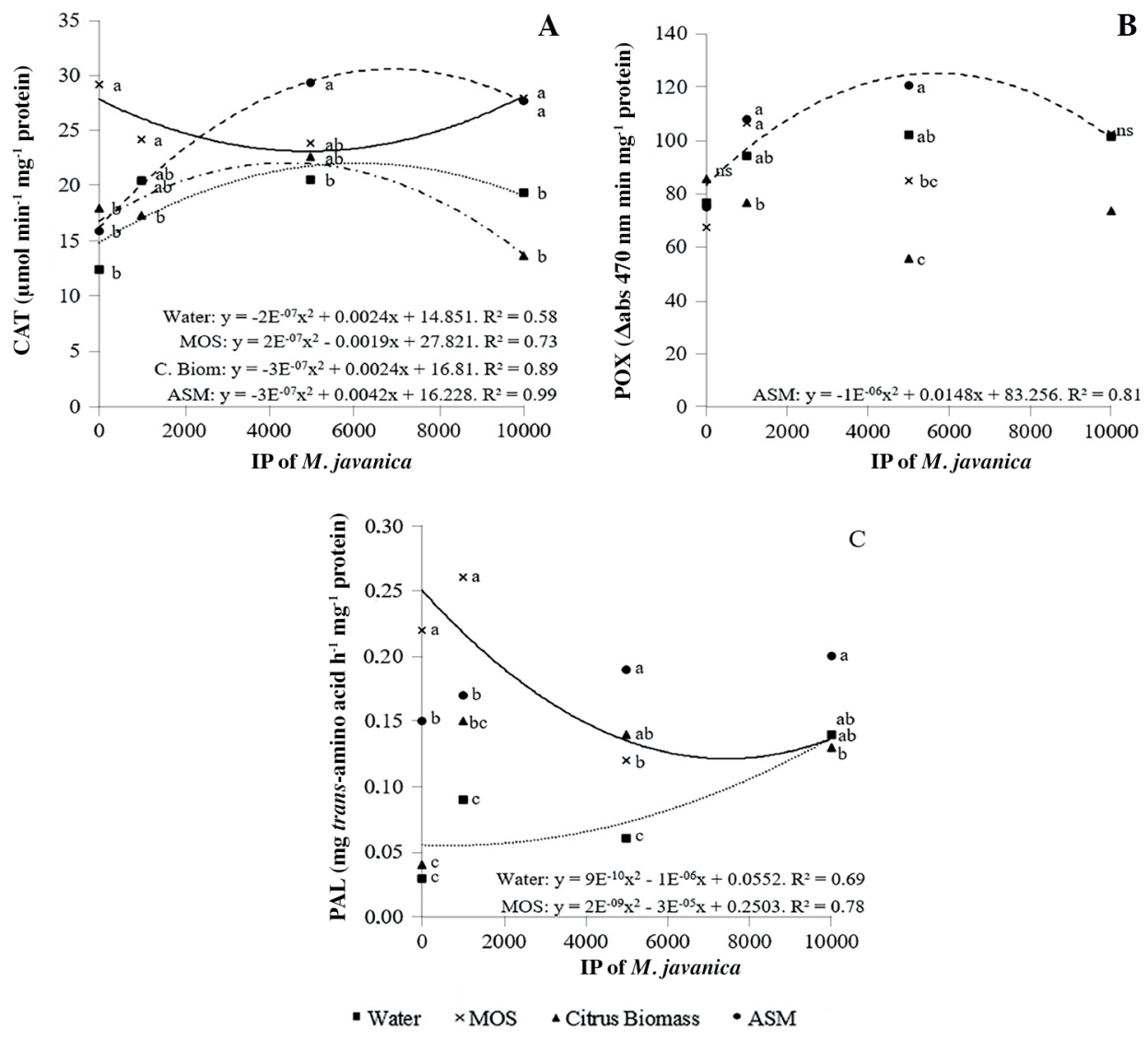

IP: Initial population; MOS: mannan-oligosaccharides; ASM: acibenzolar-S-methyl. 
As for PAL activity, there was an interaction between the induction treatments and $M$. javanica population levels (Figure 3C). The nematode levels did not affect PAL activity in plants treated with ASM and citrus biomass, although plants treated with water and MOS showed quadratic adjustments for this parameter. Enzymatic activity decreased as the inoculum level reached approximately 555 and 5000 eggs $+\mathrm{J} 2$. The MOS had the highest PAL activity $(0.22 \mathrm{mg}$ transamino acid $\mathrm{h}^{-1} \mathrm{mg}^{-1}$ protein) for the inoculum levels in the absence of nematodes, followed by ASM $(0.15 \mathrm{mg}$ trans-amino acid $\mathrm{h}^{-1} \mathrm{mg}^{-1}$ protein). Both treatments recorded higher PAL activity than the treatment with water.

A similar result was observed at the 1000 eggs $+\mathrm{J} 2$ inoculum level in which MOS promoted higher PAL activity than ASM and citrus biomass, but citrus biomass did not differ from the control. However, all inducers recorded higher enzyme activity values at the initial population of 1000 eggs $+\mathrm{J} 2$ than in the treatment without inocula. All inducers led to higher PAL activity at the 5000 eggs $+\mathrm{J} 2$ inoculum level than the control; the MOS, citrus biomass, and ASM showed PAL activity of $0.12,0.14$, and $0.19 \mathrm{mg}$ trans-amino $\mathrm{acid} \mathrm{h}^{-1} \mathrm{mg}^{-1}$ protein, respectively. Inducers did not differ from the control at the 10000 eggs $+\mathrm{J} 2$ inoculum level, although ASM showed enzyme activity that was $54 \%$ higher than citrus biomass.

\section{DISCUSSION}

The inducers under study did not increase the diameter of tuberous roots when compared to the control, regardless of the inoculum level. However, citrus biomass increased the mass of tuberous roots at the 5000 eggs $+\mathrm{J} 2$ inoculum level (Figure 1). This positive effect on the vegetative parameters of nematode-infested plants treated with citrus biomass was also observed in the soybean-M. javanica pathosystem (Puerari et al., 2013b). According to the manufacturer, citrus biomass includes polyphenols, flavonoids, phytoalexins, and organic acids. Organic acids promote nutrient absorption and enable plant growth and stress tolerance (Yildirim, 2007). Increased tuber development results from the presence of these compounds in plants subjected to moderate $M$. javanica levels.

The number of galls increased in plants treated with ASM and subjected to inoculum levels up to $5000 \mathrm{M}$. javanica eggs + J2. Subsequently, this number decreased when plants were inoculated with increased $M$. javanica population levels; this can be explained by the competition between nematodes at high population levels (Moens et al., 2010). There are other reports that inducers do not affect the number of galls (Chinnasri et al., 2003; Puerari et al., 2013a; 2013b; Miamoto et al., 2017). This can occur because these products have an effect in post-infection events by reducing nematode reproduction, but they do not reduce their penetration and the formation of feeding sites (Chinnasri et al., 2003; Molinari and Baser, 2010). The inoculum level was highlighted among the factors that could have limited the effectiveness of the MOS, citrus biomass, and ASM treatments adopted in the present study. Plant protection based on induced resistanceagainst nematodes can be partial and when plants are subjected to significantly high or more aggressive populations, this plant protection strategy may not be sufficient to ensure pathogen control; other practices must therefore be adopted to achieve integrated pest management. In addition, several factors such as cultivar, interval between inducer applications, and the appropriate rate to be applied to the pathosystem can affect the expression of plant resistance.

The hypothesis that beet plants respond to inducer applications was confirmed by increased CAT activity observed in plants treated with MOS and ASM; these plants recorded varying responses depending on the different initial M. javanica population levels. Catalase is important for $\mathrm{H}_{2} \mathrm{O}_{2}$ detoxification, that is, it catalyzes $\mathrm{H}_{2} \mathrm{O}_{2}$ decomposition into water and oxygen to protect plant cells from oxidative damage caused by ROS. Enzyme activity often occurs in peaks and exhibits increased expression on the third day after inoculation (Sahebani et al., 2011); it is higher in susceptible plants because they exhibit increased oxidative stress and accumulate more ROS. These plants show increased enzyme synthesis to combat ROS. In other words, the reduction of ROS is directly associated with increased enzyme activity and the elicitor in this case can be both the chemical product and the nematode itself. Enzyme expression was achieved at the end of the present experiment because the aim was to evaluate these parameters by focusing on tuber commercialization, that is, at the end of the crop cycle. Despite the low efficiency of the potential inducers to control both the nematodes and gall formation, they led to increased CAT activity. This enzyme plays a key role in cheese production because it is used to remove $\mathrm{H}_{2} \mathrm{O}_{2}$ from bakery products and food packaging to prevent oxidation and control food perishability (Raveendran et al., 2018).

Peroxidase activity was not affected by the potential inducers at any inoculum level. This outcome differed from several studies found in the literature, which investigated different pathosystems based on the application of different elicitors. 
Among the aforementioned studies, Melillo et al. (2006) and Nguyen et al. (2011) recorded increased POX activity due to oxidative stress caused by nematode infection and application of resistance inducers. A possible hypothesis for this outcome is that enzyme activity mainly occurs at the beginning of the infection when ROS production is high. Thus, most POX measurements were taken in the first few days after nematode inoculation. Chaves et al. (2016) reported a similar result when recording increased POX activity in sugarcane infected with M. incognita, treated with pyraclostrobin, and evaluated 5 and $20 \mathrm{~d}$ after inoculation.

The MOS and ASM increased PAL activity, which changed depending on the M. javanica population level and followed by citrus biomass. The effects of PAL activity on induced nematode resistance have been observed (Vigila and Subramanian, 2018) mainly on the third day after treatment, in which was the case with CAT. The activation of PAL is very important for plant defense because this enzyme participates in lignin biosynthesis (MacDonald and D'Cunha, 2007) and enables cell wall stiffening to reduce nematode activity in plant tissues. Although the present study conducted a late evaluation, it was possible to observe enzyme activity, which was also involved in other processes such as those adopted by the food industry. For example, L-phenylalanine is one of the two precursors necessary to synthesize artificial aspartame (Cui et al., 2014), which is used by diabetics to replace sugar (Sharma et al., 2016).

Despite the expression of defense enzymes due to plant exposure to pathogens and elicitors, it was possible to infer that this expression did not reach sufficiently high levels to reduce the nematode population. It is known that the plantMeloidogyne spp. interaction is extremely complex and evolves, which can hinder nematode control based only on the use of inducers in beet plants. Thus, it is reasonable to assume that the tuber would be discarded due to the decrease in marketability resulting from gall formation. However, this vegetable has several important compounds such as CAT, POX, and PAL enzymes that are of great interest to the food industry. Enzymes used in the food industry are mainly derived from plants, animals, and microorganisms (Kaushal et al., 2018). Tubers whose value has decreased for in natura commercialization can be used in the food industry (because they have the aforementioned enzymes and other important compounds such as betalains) to avoid food waste.

Citrus biomass application increased the weight of roots tubers, but the tested potential inducers did not reduce gall formation, number of nematodes per root system, and number of nematodes per gram of root. However, they increased the CAT and PAL activity with emphasis on MOS and ASM, which led to the highest enzyme expression. The present study recommends the use of tubers treated with inducers and those not suitable for consumption in natura in the food industry to extract enzymes (mainly CAT and PAL) or isolate other compounds of interest such as pigments.

\section{CONCLUSIONS}

In general, the potential inducers did not reduce the negative effect that nematodes have on the appearance of beet tubers, that is, there is still a decrease in the value of the product. Likewise, there was no efficient control of the nematode. However, there was an increase in catalase and phenylalanine ammonia-lyase enzymes, indicating that tubers that lose commercial value may be destined for the food industry.

\section{ACKNOWLEDGEMENTS}

We are grateful to Coordenação de Aperfeiçoamento de Pessoal de Nível Superior (CAPES), for granting the doctoral scholarship to the first author; and to Conselho Nacional de Desenvolvimento Científico e Tecnológico (CNPq), for grating the research productivity scholarship to the last author. We also thank the CNPq for funding of this research (Process 402136/2016-0). 


\section{REFERENCES}

Boneti, J.I.S., e Ferraz, S. 1981. Modificação do método de Hussey and Barker para extração de ovos de Meloidogyne exigua em raízes de cafeeiro. Fitopatologia Brasileira 6:553.

Bradford, M.M. 1976. A rapid and sensitive method for the quantification of microgram quantities of protein utilizing the principle of protein-dye binding. Analytical Biochemistry 72:248-254. doi:10.1006/abio.1976.9999.

Charchar, J.M., Oliveira, V., e Aragão, F.A.S. 2006. Extração dos espécimes de Meloidogyne das raízes de tomateiros pela técnica do liquidificador. Nematologia Brasileira 30:245-250.

Chaves, A., Pedrosa, E.R., Willadino, L., and Cardoso, M.S.O. 2016. Activation of resistance to Meloidogyne incognita in sugarcane treated with pyraclostrobin. Nematoda 3:1-7. doi:10.4322/nematoda.00516.

Chinnasri, B., Sipes, B.S., and Schmitt, D.P. 2003. Effects of acibenzolar-S-methyl application to Rotylenchulus reniformis and Meloidogyne javanica. Journal of Nematology 35:110-114.

Cui, J.D., Qiu, J.Q., Fan, X.W., Jia, S.R., and Tan, Z.L. 2014. Biotechnological production and applications of microbial phenylalanine ammonia lyase: a recent review. Critical Reviews in Biotechnology 34:258-268. doi:10.3109/07388551.2013.791660.

Glorieux, C., and Calderon, P.B. 2017. Catalase, a remarkable enzyme: targeting the oldest antioxidant enzyme to find a new cancer treatment approach. Biological Chemistry 398:1095-1108. doi:10.1515/hsz-2017-0131.

Góth, L. 1991. A simple method for determination of serum catalase activity and revision of reference range. Clinica Chimica Acta 196:143-151. doi:10.1016/0009-8981(91)90067-M.

Hernandes, I., Brito, O.D.C., Cardoso, M.R., Ferreira, J.C.A., Puerari, H.H., and Dias-Arieira, C.R. 2017. AcibenzolarS-methyl on Meloidogyne javanica control in lettuce. Acta Agriculturae Scandinavica B-Soil and Plant Science 67:660-664. doi:10.1080/09064710.2017.1329453.

Hussain, M., Kamran, M., Singh, K., Zouhar, M., Rysánek, P., and Anwar, S.A. 2016. Response of selected okra cultivars to Meloidogyne incognita. Crop Protection 82:1-6. doi:10.1016/j.cropro.2015.12.024.

Kaushal, J., Mehandia, S., Singh, G., Raina, A., and Arya, S.K. 2018. Catalase enzyme: Application in bioremediation and food industry. Biocatalysis Agricultural Biotechnology 16:192-199. doi:10.1016/j.bcab.2018.07.035.

Lusso, M.F.G., and Pascholati, S.F. 1999. Activity and isoenzymatic pattern of soluble peroxidases in maize tissues after mechanical injury or fungal inoculation. Summa Phytopathologica 25:244-249.

MacDonald, M.J., and D'Cunha, G. 2007. A modern view of phenylalanine ammonia lyase. Biochemistry and Cell Biology 85:273-282. doi:10.1139/O07-018.

Medeiros, H.A., Resende, R.S., Ferreira, F.C., Freitas, L.G., and Rodrigues, F.R. 2015. Induction of resistance in tomato against Meloidogyne javanica by Pochonia chlamydosporia. Nematoda 2:1-7. doi:10.4322/nematoda.10015.

Melillo, M.T., Leonetti, P., Bongiovanni, M., Castagnone-Sereno, P., and Bleve-Zacheo, T. 2006. Modulation of reactive oxygen species activities and $\mathrm{H}_{2} \mathrm{O}_{2}$ accumulation during compatible and incompatible tomato-root-knot nematode interactions. New Phytologist 170:501-512. doi:10.1111/j.1469-8137.2006.01724.x.

Miamoto, A., Silva, M.T.R., Dias-Arieira, C.R., and Puerari, H.H. 2017. Alternative products for Pratylenchus brachyurus and Meloidogyne javanica management in soya bean plants. Journal of Phytopathology 65:635-640. doi:10.1111/jph.12602.

Moens, M., Perry, R.N., and Starr, J.L. 2010. Meloidogyne species - a diverse group of novel and important plant parasites. p. 1-17. In Perry, R.N., Moens, M., and Starr, J.L. (eds.) Root-knot nematodes. CABI International, Cambridge, UK.

Molinari, S., and Baser, N. 2010. Induction of resistance to root-knot nematodes by SAR elicitors in tomato. Crop Protection 29:1354-1362. doi:10.1016/j.cropro.2010.07.012.

Nguyen, D.M.C., Seo, D.J., Park, R.D., Lee, B.R., and Jung, W.J. 2011. Changes in antioxidative enzyme activities in cucumber plants with regard to biological control of root-knot nematode, Meloidogyne incognita with Cinnamomum cassia crude extracts. Journal of the Korean Society for Applied Biological Chemistry 54:507-514. doi:10.3839/jksabc.2011.078.

Puerari, H.H., Dias-Arieira, C.R., Dadazio, T.S., Mattei, D., Silva, T.R.B., and Ribeiro, R.C.F. 2013a. Evaluation of acibenzolarS-methyl for the control of Meloidogyne javanica and effects on the development of susceptible and resistant soybean. Tropical Plant Pathology 38:44-48. doi:10.1590/S1982-56762013000100006.

Puerari, H.H., Dias-Arieira, C.R., Tavares-Silva, C.A., Arieira, J.O., Biela, F., and Poletine, J.P. 2013b. Ecolife ${ }^{\circledR}$ and manganese phosphite in the control of Meloidogyne javanica and in the development of soybean cultivars susceptible and resistant to the nematode. Nematropica 43:105-112.

Raveendran, S., Parameswaran, B., Ummalyma, S.B., Abraham, A., Mathew, A.K., Madhavan, A., et al. 2018. Applications of microbial enzymes in food industry. Food Technology and Biotechnology 56:16-30. doi:10.17113/ftb.56.01.18.5491.

Sahebani, N., Hadavi, N.S., and Zade, F.O. 2011. The effects of $\beta$-amino-butyric acid on resistance of cucumber against rootknot nematode, Meloidogyne javanica. Acta Physiologiae Plantarum 3:443-450. doi:10.1007/s11738-010-0564-0.

Schaffer, W.M., and Bronnikova, T.V. 2012. Peroxidase-ROS interactions. Nonlinear Dynamics 68:413-430. doi:10.1007/ s11071-011-0314-X.

Sharma, A., Amarnath, S., Thulasimani, M., and Ramaswamy, S. 2016. Artificial sweeteners as a sugar substitute: Are they really safe? Indian Journal of Pharmacology 48:237-240. doi:10.4103/0253-7613.182888. 
Tivelli, S.W., Factor, T.L., Teramoto, J.R.S., Fabri, E.G., Moraes, A.R.A., Trani, P.E., et al. 2011. Beterraba: do plantio à comercialização. Boletim Técnico IAC 210. Instituto Agronômico Campinas (IAC), Campinas, São Paulo, Brasil. Available at https://ainfo.cnptia.embrapa.br/digital/bitstream/item/48016/1/Andre-May-Boletim-Tec-IAC.pdf (accessed May 2020).

Tománková, K.L., Luhová, L., Petrivalsky, M., Pec, P., and Lebeda, A. 2006. Biochemical aspects of reactive oxygen species formation in the interaction between Lycopersicon spp. and Oidium neolycopersici. Physiological and Molecular Plant Pathology 68:22-32. doi:10.1016/j.pmpp.2006.05.005.

Umesha, S. 2006. Phenylalanine ammonia lyase activity in tomato seedlings and its relationship to bacterial canker disease resistance. Phytoparasitica 34:68-71.

Vigila, V., and Subramanian, S. 2018. Induction of systemic resistance in tomato by Pseudomonas spp. and Bacillus spp. against root-knot nematode Meloidogyne incognita. International Journal of Current Microbiology and Applied Science 6:1-10.

Yildirim, E. 2007. Foliar and soil fertilization of humic acid effect productivity and quality of tomato. Acta Agriculturae Scandinavica B-Soil and Plant Science 57:182-186. doi:10.1080/09064710600813107. 